\title{
Öğrenilen Namus Algısı Perspektifinde Kadın Cinayetleri: Muş İli Örneği*
}

\author{
Femicide in the Perspective of Learned Perception of Honor: The Case of Muş \\ Sultan Ateş ${ }^{\mathrm{a}, * *}$ \\ ${ }^{a}$ Muş Alparslan Üniversitesi, Sosyal Bilimler Enstitüsü, Siyaset Bilimi ve Kamu Yönetimi Anabilim Dalı, Güzeltepe/Muş \\ ORCID:0000-0002-0033-4444
}

\section{MAKALE BİLGİSİ \\ Makale Geçmişi: \\ Başvuru Tarihi: 26 Kasım 2020 \\ Düzeltme Tarihi: 17 Aralık 2020 \\ Kabul Tarihi: 21 Aralık 2020}

Anahtar Kelimeler:

Kadın Cinayetleri

Namus

Öğrenilen Namus

Şiddet

Toplumsal Cinsiyet

\section{ART ICLE INFO}

Article history:

Received 26 November 2020

Received in revised form 17 December 2020

Accepted 21 December 2020

\section{Keywords:}

Femicides

Honor

Learned Honer

Violence

Gender
ÖZ

Toplumsal cinsiyet çalışmalarında çok önemli bir yere sahip olan namus kavramı; Türkiye'de de cinsiyet temelli bir ayrıma tabi tutulmaktadır. Namus bu çerçeveden bakıldığında kadın için, kadın bedenine nakşedilen ve kadının hareketleri ile kontrol edilmesi gereken bir olguya işaret etmektedir. Erkek ile doğrudan ilişkilendirilmeyen namus kavramı ise kadına sahip olduğunu düşünen erkeği dolaylı yoldan etkilemektedir. Muş ilinde gerçekleșen ve namus ekseninde incelenen kadın cinayetlerinde, öğrenilen namus algısının etkileri irdelenmiştir. Çalışma sonucunda kadının bedenine ve cinsel saflı̆̆ına indirgenen namus kavramının cinayetler üzerinde önemli bir etkiye sahip olduğu görülmektedir. Muş Adliyesi'nden elde edilen iddianamelerle birincil elden kaynakların kullanıldığı bu incelemede, Muş'un toplumsal yapısını, burada namus kavramına atfedilen anlamı, namusun öğrenilme biçimini, tutkunun kadın merkezli oluşunu ve erkeğin namus kavramını kullanış gerekçesini görmek mümkündür.

\section{Giriş}

$\mathrm{Bu}$ çalışmada Muş ilinde gerçekleşen kadın cinayeti örneğinde namus algısı ve cinayetler arasındaki ilişkiye dair değerlendirmelere yer verilmiştir. Namus olgusunun toplum ve aile ayağı elde edilen örnek olayda tüm detaylarıyla ele alınmaktadır. Çalışmaya konu olan vaka örneğinde namustöre ve arzu kavramları eksen olarak belirlenmiştir. Namus algısının öğrenildiği kabulü üzerinden hareket edilmekte ve bu bağlamda toplumsal yap1, ataerkillik ve geleneksel kabuller ilişkilendirilerek tartışılmaktadır. Çalışmada nitel araştırma yöntemi olarak veri toplama yöntemi kullanılmıştır. Bu doğrultuda doküman analizi yapılmış ve kamu kaynaklarından (mahkeme tutanakları, adli tıp kaynakları) faydalanılmıştır. Çalışmanın temel problemi olan namus algısının cinayet üzerindeki güçlü etkisinin toplumsal yapıyla olan etkileşimi tartışılmıştır. İncelendiğinde namus bahaneli cinayetlerde geleneksel aile

* Bu çalışma, 22-23 Ekim 2020 tarihlerinde Muş Alparslan Üniversitesinde düzenlenen II. Uluslararası Muş Sempozyumunda sözlü bildiri olarak sunulmuştur.

** Sorumlu yazar/Corresponding author.

e-posta: sultan.ates3347@gmail.com 
yapısı ve bu yapının değiştirilemez kabulleri önemli rol oynamaktadır. Toplumsal düzen ve bu düzenin ahlak, namus, töre gibi kelimelere yükledikleri anlamlar doğrultusunda insanlar davranış sergilemektedir. Bu davranışlar nesilden nesille aktarılan değiştirilemez değerlere dönüşmektedir. Genel geçerliliği olmayan ve göreceli olan bu öğrenilmiş davranışlar her zaman iyiye güzele hizmet etmemektedir. Örneğin öğretilen namus algısı kadın bedenine nakședilen ve kadının öldürülmesinde kullanılan tehlikeli değerlerdendir.

Çağımız haklar dünyasında önemli insan hakları ihlali olarak görülen kadın cinayetleri hem ulusal hem de uluslararası kamuoyunda dikkatle takip edilen bir olgudur. Toplum sağlığını olumsuz yönde etkileyen bu olgu; siyasal, sosyal, ekonomik ve kültürel pek çok platformda farklı şekillerde ve formlarda dile getirilmektedir. Yapılan çalışmalar ve tartışmalar kadına yönelik şiddet ve kadın cinayetleri ile ilgili toplumsal cinsiyet ayrımı, ataerkillik, geleneksel aile yapıları, töre, namus gibi kavramlarında tartışılması gerektiğini ortaya koymuştur. Özellikle namus kavramının kadın ve erkek için değişen anlamı kadın cinayetlerinin temel sebebi olabilmektedir. T.C. Başbakanlık Kadının Statüsü Genel Müdürlüğü, "Töre ve Namus Cinayetleri ile Kadınlara ve Çocuklara Yönelik Şiddetin Sebeplerinin Araştırılarak Alınması Gereken Önlemlerin Belirlenmesi Amaciyla Kurulan TBMM Araştırma Komisyonu Raporu'na göre “töre ve namus adına uygulanan şiddet ve işlenen cinayetler kaynağını toplumun köklü alg1 ve geleneklerinden almaktadır. Cinsiyet temelli inşa edilen namus algısı, kadın için, kadın bedenine nakşedilen ve kadının hareketleri ile kontrol edilmesi gereken bir olguya işaret etmektedir. $\mathrm{Bu}$ pencereden okunan namus olgusu kadının cinsel saflığına denk düşmektedir. Erkek ile doğrudan ilişkilendirilmeyen namus kavramı ise kadına sahip olduğunu düşünen erkeği dolaylı yoldan etkilemektedir. Erkeğin dolaylı yönden etkilemesini sağlayan öğretiler aile ve toplum tarafindan üretilmektedir. Aile tarafindan belirlenen kurallar dişında hareket eden kadının davranışları utanç kaynağı olarak görülmekte ve kadının davranışları ile ailenin onuru bu anlamda paralellik göstermektedir. $\mathrm{Bu}$ açıdan namus, ailenin toplum içindeki değerini ve itibarını temsil eden bir olgu olarak karşımıza çıkmaktadır. Erkek tarafından ailenin değer ve itibarının korunması, kadının cinsel davranışlarının kontrolü ile sağlanmaktadır.

Toplumsal normlar tarafindan kontrol altında tutulan ve bireylere kadın bedeni üzerinden haklar sunan namus kavramı, kullanılıș şekli açısından tehlike arz etmektedir. Kadının öldürülmesi için yeterli görülen bu olgu nedeniyle erkek hem toplum nezdinde onure edilmekte hem de gerçekleştirdiği cinayetin meşruluğuna vicdani olarak da ikna edilebilmektedir. Bakıldığında toplumsal alanda ve aile içinde geleneksel kabuller ile tanımlanan namus olgusu, aile bireylerine ve özellikle de ailedeki erkeklere küçük yaşlardan itibaren öğretilmektedir. Öğrenilen namus algısı ile hareket eden bireyler, namus gerekçesi ile kadının hareketlerine anlamlar yüklemekte ve yüklediği anlamlarla eylemlerini gerçekleştirmektedir. Hamzaoğlu ve Konuralp (2019: 52)'a göre özellikle aşırı gelenekçi toplumlarda bu öğreti namusu kadının cinsel saflığıyla ilişkilendirilmekte ve töre tarafindan belirlenmiş cinsel sakınma kurallarına aykırı hareket eden kadın için verilen ceza ölüm şeklinde belirlenmektedir. $\mathrm{Bu}$ açıdan bakıldığında namus cinayetleri tam da bu şekilde ortaya çıkmaktadır. Özellikle ataerkil yapıya geçişten sonra kadının cinsel denetimi erkek egemen sistemin temelini oluşturmaya başlamıştır. Engels (1986:54) yapmış olduğu çalışmada, anaerkil dönemde ensest ilişki dışındaki ilişki biçimlerinde cinsel özgürlükle beraber kadın erkek eşitliğinin olduğu ve ensest ilişki dışındaki ilişki biçimlerini cezalandırılmadığı vurgulamaktadır. Soy bağının baba üzerinden izlenmesiyle birlikte kandaş toplumlarda artık cinsellik kadın aleyhine örgütlenmeye başlamıştır. Temelde cinselliğin kontrolü ile ilişkilendirilen namus cinayetleri de bu toplumlarda görülmeye başlanmıştır. Ataerkil toplumlarda, toplumsal cinsiyet ayrımının önemli bir örneği olan namus olgusu erkek ile kadın arasındaki cinsiyet farkının doğal bir sonucu olarak meşrulaştırılmaktadır. Bu meşruiyetle birlikte roller tanımlanmakta ve bu roller bireylere empoze edilmektedir. Namus cinayetlerinde kadına tanımlanan toplumsal cinsiyet rolleri de eylemi gerçekleştiren tarafindan kullanılan araçlardandır. Russel' e göre; "Kadın toplum tarafindan artık her şeyden önce kocaya eş, çocuğa anne seçilmiştir ki bu sebeple ailenin bir ferdi olarak da öncelikle onun korunması gerekmektedir. Batı uygarlığında da Doğu uygarlığında da cinsel etiğin ilk amacı kadının namusuna sahip çıkmak olmuştur. Çünkü onsuz babalık belirsizleşeceği için ataerkil ailenin de varlığı tehlikeye girecektir'(Russel, 2014: 6). Ataerkil toplumlarda toplumsal cinsiyet eşitsizliğinin doğurduğu roller kadına mutlak itaat ve koşulsuz sadakat yükümlülüğü getirmektedir. İtaatsizliğin ve sadakatsizliğin bedeli de toplum tarafindan en ağır şekilde cezalandırılabilmektedir. $\mathrm{Bu}$ toplumlarda kesilen cezalar, konulan kurallar, gelenekler, değer yargıları, namusa bakış açısı gibi pek çok konu nesilden nesille aktarılarak, öğretilerek varlığını sürdürmektedir.

\section{2. Şiddet, Namus ve Ataerkillik}

Şiddet dilimize Arapçadan gelen bir kelime olup Türk Dil Kurumu tarafindan, bir hareketin, bir gücün derecesi, yeğinlik, sertlik; hız; bir hareketten doğan güç; karşıt görüşte olanlara kaba kuvvet kullanma; kaba güç; duygu ve davranışta aşırılık olarak tanımlamaktadır (TDK, 2020). Şiddet doğası gereği daima örtük ve karanlık bir tarafı temsil etmektedir. Genel anlamda şiddet değerlendirildiğinde bedene ve ruha yapılan müdahale olarak düşünülebilir. İnsanlık tarihi ile paralel bir şekilde varlığını devam ettiren şiddet olgusu toplumsal düzende kazanan tarafi temsil etmiştir. Rafeel Moses (1996: 23)'e göre çoğu zaman şiddet, ya içgüdüsel ve bu nedenle toplumsallaşma sürecinde çok az değişen, ya da sadece ve sadece çevresel etkenlerden kaynaklanan bir davranış olarak görülür. $\mathrm{Bu}$ açıdan değerlendirildiğinde zamana ve koşullara göre formu değişen "şiddet", popülerliğini sürdürmektedir. Şiddet motifi kulağa ilk etapta fiziksel şiddet şeklinde kendini hissettirse de zamanla türlere ayrılmıştır. Günümüzde fiziksel şiddetin yanı sıra psikolojik (duygusal) şiddet, ekonomik şiddet ve cinsel şiddet de azımsanamayacak kadar yaygın hale gelmiştir. Şiddeti türleriyle birlikte mikro düzeyde değerlendirdiğimizde, araç olarak kullanan bireyleri öncelikle aile içinde daha sonra toplumsal düzende ele almak gerekmektedir. Toplumsal kesimlerin tamamını etkisi altına alan şiddetin aile içi şiddet ayağı; kadınlar, çocuklar ve yaşlılar üzerinde önemli izler bırakmaktadır. Yapılan çalışmalarda şiddetin alt kümesi 
olarak görülen aile içi şiddet olgusuna s1kça rastlanılmaktadır. Aliye Mavili Aktaş’a göre,

"Şiddet, bireyin bedensel ve ruhsal açıdan zarar görmesine, yaralanmasina ve sakat kalmasina neden olan bireysel ve toplu hareketlerin tamamidır. Aile içi şiddet ise, bu davranış ve eylemlerin aile içinde gerçekleşmesidir. Aile içi şiddet büyük oranda kadın ve çocuklara nadiren de yaşlılara yönelik olmaktadır" (Aktaş, 2006: 151).

İncelendiğinde aile içinde varlığını sürdüren şiddet olgusu toplumsal tabakaların tamamına yayılmaktadır. Kadınları, çocukları ve yaşlıları önemli oranda etkileyen aile içi şiddet beraberinde pek çok sorunu da getirmektedir. Bu açıdan özellikle toplumsal alanda kadına yönelik şiddetin iyi okunması gerekmektedir. 6284 sayılı Aile Korunması ve Kadına Karşı Şiddetin Önlenmesine dair kanunun 2'nci maddesinin d bendi kadına yönelik şiddeti şu şekilde tanımlanmıştır:

"Kişinin fiziksel, cinsel, psikolojik veya ekonomik açıdan zarar görmesiyle veya acı çekmesiyle sonuçlanan veya sonuçlanması muhtemel hareketleri, buna yönelik tehdit ve baskıyı yada özgürlüğün keyfi engellenmesini de içeren, toplumsal, kamusal veya özel alanda meydana gelen fiziksel, cinsel, psikolojik, sözlü veya ekonomik her türlü tutum ve davranıştır"'(6284 sayll kanun, 2012:2).

Kadına yönelik şiddeti tek bir türe veya çevreye indirgemeden içinde barındırdığ 1 dinamiklerle değerlendirmek gerekmektedir. Kadına yönelik şiddet denildiğinde akla ilk gelen olgu erkek şiddetidir. Oysaki tek başına erkek şiddetiyle ilgisi olmayan kadına yönelik şiddet, kompleks bir çevreyle ilgilidir. Geçmişten günümüze kadına yönelik şiddet; kadın bedeninin, kadının doğurganlığının ve kadının üretim güzcünün kontrolü ile varlığını sürdürmektedir. Kadının kontrolü ile aktif hale getirilen şiddet olgusu; özellikle cinsiyet ayrımcılığı ve toplumsal cinsiyet rolleriyle beslenmektedir. Toplum tarafindan üretilen ve geleneksel kabullere dönüşen toplumsal cinsiyet rolleri, hem kadının hem de erkeğin davranış biçimlerine şekil vermektedir. Connel (2016: 63) toplumsal cinsiyet rollerinin öncelikle Simone de Beauvoir, TalcottParsons ve Margaret Mead gibi yazarlar tarafindan toplumsal cinsiyet örüntülerinin evrensel olarak gördükleri çekirdek aile içerisindeki ilişkiler kapsamında tanımlandığını ifade etmektedir. Engels (2008)'e göre ise özel mülkiyet ile birlikte anaerkil dönem son bulmuş, soya bağl1 ailelerin oluşumuyla birlikte kadın ve erkeğin toplumsal cinsiyet rollerinin kadının erkeğin egemenliği altına girmesi yönünde şekillenmiştir. Bakıldığında toplumsal cinsiyet rollerinin değişim ve dönüşümü aile içinde özellikle ataerkil toplumlarda şekillenmektedir. $\mathrm{Bu}$ rollerin belirlenmesinde kullanılan ana argüman erkeksilik ve kadınsılık vasıflarıdır. Doğumla birlikte belirlenen kadın veya erkek cinsiyeti toplum tarafından kadınlık ve erkeklik olarak değiştirilmektedir. Kadınlık bu anlamda naiflik, muhtaçlıkla; erkeklik ise güç, kuvvet ve liderlikle bağdaştırılmaktadır. $\mathrm{Bu}$ ayrım beraberinde kadına yönelik şiddet ile pek çok toplumsal soruna da getirmektedir. Vandello ve Cohen'e göre;

"Kültürel değerler ve normlar erkeksi ve kadınsı davranışları vurgulamaktadır. Bu nedenle, erkeksilik gereğ $i$ erkekler gerektiğinde kadınlara şiddet uygulayabilir ve kadınsılık gereği kadınlar erkeklerin bu tür şiddet içeren davranışlarını affetmek ve kabul etmek durumundadır" (Sakallı Uğurlu ve Akbaş, 2013:80'den alıntı).

Kültürel değerler ve normlar tarafindan erkeksilik ve kadınsılık baz alınarak yaratılan roller ile birlikte bu rollerin ihlali pek çok yaptırımı daberaberinde getirmiştir. Özellikle kadın bedeninin kontrolü ile yaratılan rollerde kadından yüzde yüz itaat beklenmektedir. İncelendiğinde bu noktada namus olgusunun varlığı ilk göze çarpan etkendir. Türkiye'de namus terimi hem erkek hem de kadın için farklı anlamlara gelecek şekilde kullanılmıştır. Türk Dil kurumunun yapmış olduğu tanımlamada namus; "bir toplum içinde ahlak kurallarına ve toplumsal değerlere bağlılık, iffet, doğruluk, dürüstlük" şeklinde ifade edilmektedir (TDK, 2020). Tanımlamada herhangi bir cinsiyet ayrımı yapılmamasına karşın toplum tarafindan kadın ve erkek için namus kavramı farklı anlamlara gelmektedir. Örneğin "namussuz erkek" demek daha çok erkeğin güvenilmezliğine vurgu yaparken "namussuz kadın" ifadesi kadının cinsel saflığını ve sadakatini koruyamaması ile ilişkilendirilmektedir. Kadın ve erkek için ayrı anlamlara gelen namus kavramı şiddetin ana gerekçesi haline gelebilmektedir. Doğan $(2016,87)$ 'a göre şiddete neden olan namus kavramı, birey dişında bireyin mensup olduğu aileyi ve toplumu da ilgilendiren kolektif bir kavramdır. Bu kolektif yapı içerisinde kadın ve erkeğin sorumluluğu, kadın ve erkek için namus kavramına getirilen anlam bazında değişiklik göstermektedir. Erkeğin namussuzluğu (itibar kaybı) tolere edilebilmekteyken kadının namussuzluğu (cinsel saflığı ve sadakatin kaybı) ölümle sonuçlanabilmektedir. Doğan, namusun kolektif tarafina şöyle bir yorum getirmektedir:

"Şiddete neden olan namus kavramında, gurupta oluşan şiddet veya öldürme beklentisi, namusun kolektif kimliğin bir parçası olarak kabul edilmesi ve namusun kadınların cinsel masumiyetiyle özdeşleştirilmesi düşüncesinden kaynaklanır" (Doğan, 2016: 90).

Bakıldığında ailenin ve erkek bireylerin dolaylı yönden etkilendiği namus kavramı kadının cinsel saflığına denk düşmektedir. $\mathrm{Bu}$ namus anlayışına göre dolaylı yönden etkilenen erkek; hem kendi namusunu hem de ailesinin namusunu denetim altına alıp koruma görevini üstlenmektedir. Erkeğin kadını bu şekilde koruma altına alarak sahiplenmesi namus kavramının sürekliliğine sebep olmaktadır. Özellikle ataerkil toplumlarda ve geleneksel aile yapılarında bu sahiplenme görevi doğumla birlikte erkeğe empoze edilmeye başlanmaktadır. Ataerkillik özü itibariyle babanın soyuna bağlı olmayı ifade eden bir kavram olarak karşımıza çıkmaktadır. Gizem Çelik'in ifadesiyle ataerkillik şu şekildedir:

"Ataerkillik en yalın ifadeyle, erkek egemenliğinin hüküm sürdüğ̈̈ toplumsal yapıyı ifade eden ataerkil, kadınlık ve erkeklik rollerinin yani toplumsal cinsiyet rollerinin erkeklerin iktidarı odağında oluştuğu, kadının ikincileştiği, ĕger derin bir inceleme ve sorgulama gerçekleştirilirse aslında erkeğin de başka "güçlü" erkekler tarafindan ezildiği bir yapıyı anlatmaktadır"(Çelik, 2017:56).

Ataerkil aile yapısı içinde erkeğin daha güçlü erkeğe tabi olması, kadının ise ailenin tamamına karşı sorumluluğu göze çarpmaktadır. Erkek ve kadın için farklı anlamlarda kullanılan ve bu tarafiyla cinsiyetçi bir özelliğe sahip olan namus kavramı, ataerkil aile yapılarında değiştirilemez 
normlar arasındadır. Ataerkil toplumlarda şiddetin temel aracı haline gelen bu kavram kadının öldürülebilmesi için kullanılabilen önemli bir materyaldir. Ataerkil aile yapılarında kadının namusundan sadece kadının bağlı bulundu eş veya aile sorumlu değildir. $\mathrm{Bu}$ sorumluluk ailenin baba tarafindan soy bağı ile bağlı olduğu bütün bir aileyi kapsamaktadır.

\section{3. Öğrenilen Namus Algısı ve Örnek Olay}

Erkek ve kadın için farklı anlamlarda kullanılan namus kavramı değişen oranlarda ve ağırlıkta kadın ve erkeğe sorumluluklarda yüklemektedir. Ecevitoğlu (2012: 279) erkeğin ve kadının namus ile ilgili üstlendikleri rolleri, kadının toplumun biyolojik olarak yeniden üretilmesinde üstlendiği rolle kendini nesnelleştirdiğini ve buna paralel olarak da namus adı verilen değerin taşıyıcısı olarak kodladığı yönündedir. Erkek için ise namus kavramı, kandaş olduğu guruptaki bütün kadınlar üzerinde söz sahibi olmasını sağlayan bir değerdir. . Hamzaoğlu ve Konuralp’a göre kadın cinselliğinin denetimiyle başlayan ve binlerce yıldır devam eden toplumsal ve siyasal iktidarların eril niteliği, kandaş toplumlardan günümüz modern toplumlarına kadar geçerliliğini korumuştur. Toplumsal cinsiyet eşitsizliğinin temeli olan bu sembolik iktidar, toplumsal platformda kadına ve erkeğe hiyerarşik bir yapı oluşturmuştur. Namus kavramı ile şekillenen sorumluluklar toplumsal cinsiyet rollerinin oluşmasında kullanılan önemli bir motiftir. Cinsiyetin oluşumuyla birlikte bireylere bu roller öğretilmekte ve bu rollere itaat edilmesi beklenmektedir. Bireylere yüklenen sorumluluklarla ve yasaklarla sosyal düzen hem korunmakta hem de kendi içinde yaptırımları olan bir sisteme dönüşmektedir. Doğan kadın ve erkek ayrımıyla; toplumun bu sistem içinde yer alan bireylerden namusu baz alarak beklentilerini şöyle özetlemektedir:

"Namuslu erkek, erkek gibi davranmall ve erkeksi davranışlar sergilemeli, namuslu kadın ise davranışlarında ve giyiminde mütevazı olmalıdır. Erkeksi olmayan adam ve mütevazı olmayan kadın, kendi cinsine ve doğaya ihanet etmişs sayılır (Doğan, 2016: 93).

Bakıldığında toplumun değer yargılarına göre şekillenen erkeklik ve kadınlık rolleri bireylere çocuk yaşlarda öğretilmektedir. Kadınlık rollerinin erkek bireylere ve ailenin diğer üyelerine göre şekillendiğini söylemek mümkündür. Örneğin sosyal hayattan kısıtlanan kadınların bu kısıtlamaya maruz kalmalarının altına yatan sebep kadının ev içi alandaki iş yükümlülüğü ile ilgilidir. Kadının çocuk bakma, ev işlerini yürütme, yaşlı bakımı gibi görevleri kanunlaşmış görevler olarak kadına empoze edilmektedir. Bunların dışında şiddetin beslendiği önemli araçlardan biri olan namus kavramı da kadın ve erkek için farklı sorumluluklar getirmektedir. Hamzaoğlu ve Konuralp namus olgusunun kadın ve erkek için yüklediği sorumlulukları şöyle ifade etmektedir:

"Kadın açısından namus, kadınların uymaları gereken cinsel kurallardır. Bu kurallar ise kadınlarin evlenene kadar bekâretini korumalart ve evlendikten sonra da kocaları dışında başka erkeklerle cinsel ilişkide bulunmamalarıdır. Erkek açısından namus algısının kaynă̆ının kadın olmasında eril şiddetin gerekçesini de buluruz. Toplumsal yaşamda erkek açısından namus; karısının, kızının, kız kardeşinin, annesinin ve akraba kadınların cinsel saflı̆̆ıdır" (Hamzaoğlu ve Konuralp,2019: 54).

$\mathrm{Bu}$ tanımlamalar 1şı̆̆ında şekillenen erkek ve kadın karakteri, kadına boyun eğmeyi erkeğe ise kurallara uymayan kadına yaptırım uygulamayı öğretmektedir. Bu şartlar altına büyüyen erkek için artık şerefli yada şerefsiz olmak kadının cinsel saflığına ve sadakatine bağlıdır. Zira namus cinayetlerine bakıldığında erkeğin kendini şerefsiz olarak nitelendirmektense kadını öldürmeyi tercih ettiği görülmektedir. Erkeği bu tercihe iten sebeplere bakıldığında namusun pek çok dinamiği olduğu görülmektedir. Birleşmiş Milletler Kalkınma Programı (UNDP) ve Birleşmiş Milletler Nüfus Fonu (UNFPA) ile Nüfusbilim Derneğinin 2014 yılında Şanlıurfa, Batman, Adana ve İstanbul illerinde yapmış olduğu araştırmada namus cinayetlerinin dinamikleri şu şekilde sıralanmıştır:

"1. Namus, kadın ile, kadın ve erkek arasındaki cinsel ilişkilerle, genç kuzların bekaretiyle, ve evlilikteki sadakatsizlikle bağlantıl bir kavramdır. Aileyi, toplum kurallarını ve gelenekleri korumak adına kadınlar erkeklerin kontrolü altında tutuluyorlar. Bu, dört şehirde ve farklı insan grupları arasında daha yaygın yaklaşım gibi görülüyor. Kadınlar, özellikle de genç kadınlar arasında bu yaklaşıma karşı olumsuz görüşler geliştiği hissediliyor.

2. Namus, toplumda, işyerinde ve aile içerisinde dürüst bir hayat sürmekle băglantıll ahlaki değerleri ve iyi davranışları kapsaması gereken daha geniş bir kavramdır. Bireyler istedikleri taktirde böyle yaşamayl seçebilirler. Insanlar bazen bunu kendileri ve çocuklart için yaparlar, bazen de toplumları, milletleri, ülkeleri vs. için.

3. Toplumumuzda genel olarak anlaşıldiğı şekliyle namus yıkıcı bir kavramdır, çünkü insanların özellikle de kadınların özgürlüğ̈̈nü, yalnızca aile içinde değil fakat tüm toplum içinde erkeklerin kontrolü altına sokarak kisitlamaktadır"(UNFPA, 2016: 17).

Bakıldığında araştırmada yer alan kişilerin önemli bir çoğunluğu namus olgusuna öğretilen değerler ve normlar çerçevesinde yanıtlar vermiştir. Namus cinayetlerinde cinayete neden olan faktörlerin başında sosyoekonomik koşullarla ile birlikte toplumsal baskılar gösterilebilir. Bireylerin çocuk yaşlarda öğrenmeye başladıkları namus olgusu koşulların oluşmasıyla eyleme dönüşebilmektedir. Eylemin gerçekleşmesi ise toplumsal baskının bireyde oluşturduğu korkuyla paraleldir. Başka bir deyişle birey; toplumun baskısını, kışkırtmalarını beklemeden namusunu temizlemeyi düşünmektedir. Namus kavramı sadece bekar kadınların cinsel saflığıyla ilişkilendirilmemekte aynı zamanda evli olan kadınlarında evlilik sona ermiş olsa dahi sadakatini korumasıyla ilişkilendirilmektedir. Birleşmiş Milletler Kalkınma Programı ve Birleşmiş Milletler Nüfus Fonu işbirliği ile hazırlanan Türkiye'deki Namus Cinayetlerinin Dinamikleri Eylem Programı İçin Öneriler Sonuç Raporu (2005: 29) verilerine göre namusun görülme şekilleri şu şekilde sıralanmıştır:

Evli bir kadının evlilik dışı ilişki kurması toplumdaki namus anlayışı çerçevesinde namuslu kadın imajına ters düşen bir durum olarak görülmektedir. 
- Evli bir kadının bir erkekle kaçması durumu da evlilik dıșı ilișki kurma kategorisinde değerlendirilmesine rağmen sonuçları bakımından farklılık gösterebilmektedir.

- Evli bir kadının boşanması/kocasını terk etmesi de yine namus olgusu içinde değerlendirilen ve halk arasında "gelinliğinle girdiğin evden kefeninle çıkarsın” ifadesine ters düşmektedir.

- Boşanmış bir kadının bir erkekle ilişki kurması iki tarafin aileleri ve eski koca tarafindan kabul edilebilir bir durum değildir. Aileler ve eski kocanın kadın boşanmış olsa dahi kadının bedeni ve cinselliği üzerindeki söz hakkı namusa yükledikleri anlam kapsamındadir.

- Bekâr bir kızın bir erkekle ilişki yaşaması durumunda ya da sadece erkeğe beslenen duygunun açığa çıkması bile namusa aykırılık için yeterli görülmektedir.

- Bekâr bir kızın bir erkekle kaçması iki taraf içinde ağır sonuçlara sebebiyet verebilmektedir.

- Evli veya bekâr bir kadının kaçırılması/tecavüze uğraması durumunda kadının yaşamış olduğu travmaya ek olarak ailelerin çözüm yolları kadın için daha ağır olabilmektedir.

Çalışmaya konu olan namus cinayeti evli bir kadının öldürülmesini konu edinmiştir. Çalışmada Muş ilinde kayıt altına alınan bir cinayete yer verilmiştir. Cinayetle ilgili tüm veriler resmi izinler sonucunda Muş Cumhuriyet Başsavcılığından temin edilmiştir. İçerik çözümlemesi yapılan vakada namus temel eksen olarak yer almıştır. Ele alınan örnekte Muş ilinin toplumsal yapısı, geleneksel aile bağları, ataerkillik, kadınlığa ve kadının namusuna atfedilen özel anlam gibi kavramlar paralelinde değerlendirmelere yer verilmiştir. Aşağıda detaylandırılacak olan vakada toplumsal cinsiyet rollerinin kadın cinayeti üzerindeki rolü, öğrenilen namus algısı ve kadınlığın erkeklik tarafından algılanış biçiminin cinayet üzerideki etkileri irdelenmektedir. Namus cinayetlerinde kadının yakın ilişkiler içinde olduğu erkekler tarafindan öldürüldüğü görülmektedir. Bu vakada da yer alan kadın kan bağı ile bağlı olduğu aile bireylerinden biri tarafindan katledilmiştir. Vakayı detaylandırmadan önce göze çarpan ilk olgu ruhsal bozukluğu olan bireyin kadını namus gerekçesiyle katletmesidir.

Örnek olay incelendiğinde; 14 Mayıs 2017 yılında Muş merkezde gerçekleşen vakada öldürülen kadın altmış beş yaşında bir annedir. Annesini öldürmekle suçlanan sanık ise yirmi yedi yaşında, ailesiyle yaşayan ve herhangi bir işte çalışmayan erkek bireydir. ${ }^{1}$ Vakada ailesiyle birlikte yaşayan sanık E.K.'nın ağır psikolojik sorunları olduğu iddiası yer almaktadır. Namus cinayetlerine bakıldığında sanıklar ya on sekiz yaş altı çocuklar (yeni yasayla namus gerekçesiyle öldürme eylemini gerçekleştiren çocuk yaştaki

\footnotetext{
${ }^{1}$ Çalışmada kullanılan kodlar, kişilerin ad ve soyadlarının kısaltmaları değildir.
}

suçlulara herhangi bir indirim uygulanmamaktadır) tarafindan gerçekleştirilir yada sanıklar ruhsal bozukluğu gerekçe olarak göstermektedir. İki durumda da amaç cezai indirimdir. Bunun yanında tıbben ruhsal bozukluğu bulunan bireylerin de namusu gerekçe göstererek öldürme eylemini gerçekleştirdikleri görülmektedir. Bu bağlamda çalışmaya konu olan cinayet vakasinda da sanı tıbben ruhsal bozukluğu kanıtlanan bir bireydir. Olay incelendiğinde maktul S.K. olay günü saat 11:00 sularında evde tek başına olan oğlu E.K tarafindan boğularak öldürülmüştür. Sanık olay sonrası üst komşularını tehdit ederek salonlarının ortasında dua ederek beklemeye başlar. Sanığın şüpheli davranışlarından korkan komşuları sigara alma bahanesiyle evden ayrılır. Komşuları evi terk ettikten sonra polisi arayarak sanığın tutuklanmasını sağlar. Olay esnasında evde bulunmayan baba F.K. olaydan yirmi beş dakika sonra eve gelir ve eşini baygın halde bulur. Hastaneye kaldırılan maktul S.K. olaydan on saat sonra yaşamını yitirir.

Yapılan soruşturmada tanıkların ortak beyanı sanı̆̆ın ruhsal bozukluğu olduğu yönündedir. Savcılık tarafindan alınan ifadede sanık, annesini öldürdüğünü şu sözlerle beyan etmektedir:

“...annem olan S.K.'yı ben öldürdüm. Öldürme sebebim ise, namussuzluk yapmış olmasıdır. Kendisini de bu konuda daha önce uyarmıştım. Yapacă̆ım demiştim ve yaptım. Benim rahatsızlığım vardır. Kafamda cisim bulunmakta, ancak ben ilaç tedavisini istemiyorum..."

Sanı̆̆ın ve tanıkların ifadesi sonucu Elazı̆̆ Ruh ve Sinir Hastalıkları Hastanesinde tedavi gören sanıkla ilgili rapor şu şekildedir:

"şüphelinin psikotik bozukluk denilen ruhsal rahatsızlı̆̆a duçar olduğunu, işlediği fiilin hukuki anlam ve sonuçlarını algılama ve bu fiille ilgili olarak davranışlarını yönlendirme yeteneğinin önemli derecede azalmış olduğunu, bu nedenle suç tarihinde suçuna karşı ceza-i ehliyetinin bulunmadı̆̆ına dair oy birliğiyle karar verildiğ $i$ "

Muş ilinde gerçekleşen bu cinayet örneği öğrenilen namus algısı başlığı altında değerlendirilmiştir. Bakıldığında sağlıksız bir bireyin namusu kullanış şekli ve namusa yüklemiş olduğu anlam kadın cinselliği merkezlidir. Sanığın ifadesinde öldürdüğü annesi için "namussuzluk yaptı" iddiası, ruhsal bozukluğu olan bireyinde çocuk yaşlarda öğretilen namus algısını özümsediğini gözler önüne sermektedir. Toplumsal yapı içerisinde kadının namusunu korumasının erkeğin onuruyla denk düşmesi namus motifinin, toplumun tüm kesimlerinde hayati öneme sahip olmasını sağlamaktadır. Toplumsal yapı içerisinde ögrenilen namus algısı erkeğin iktidarının önemli bir aracıdır. İktidarlığını koruma altına almak isteyen namus algısı varisleri, koruma altına aldıkları bu değeri nesilden nesille aktarmaktadır. Namusun kullanılış şekli, olayın gerçekleştiği yerin toplumsal yapısı, kadınlığa ve kadın merkezli namus kavramına yüklenen anlamı, çalışmanın örnek olay kısmında görmekteyiz. Namus kavramı toplumsal düzende sağlıklı sağlıksız tüm bireylere kadın merkezli öğretilmekte ve koşullar sağlandığında itibar için çekinmeden kullanılabileceği aşılanmaktadır. Örnek olayda yer alan sanığın akli dengesinin yerinde olmaması, gerçekle irtibatının kopması bile namus kavramına sahip olduğu gerçeğinin değiştirmemektedir. Sanığın namusu gerekçe 
göstererek eylemini gerçekleștirmiş olması geleneklerin toplumsal değişime karşı göstermiş olduğu direnişin başarısı olarak görülebilmektedir. Zira sanık geleneklerin öğretileri ile büyüyerek gelenek ve kişilik arasında güçlü bir bağ kurmuştur. Akli dengesi yerinde olamayan bireyin de duyarak ve görerek davranışlar geliştirebileceği görülmektedir. Ailenin yaşam şekli, toplumla etkileşimi, kadına bakış açısı, namusa atfettiği değer gibi pek çok dinamik, akli dengesi yerinde olamayan bireye de başarılı bir şekilde aktarılmıştır. En nihayetinde sanık, öğrenmiş olduğu değer yargılarından biri olan namus olgusunu kullanarak annesini katletmiştir.

\section{Sonuç}

Kadın cinayetleri hem ulusal hem de uluslararası platformda önemli bir toplumsal mesele olarak varlığını sürdürmektedir. Sadece Türkiye de internet platformu olan Anıt Sayaç'ın kayıt altına aldığı 2020 yılına ait 245 kadın cinayet vakası yer almaktadır. Dünyada ve Türkiye de kadın cinayetleri vakalarına bakıldığında cinayetler en kaba tabiriyle namus, töre ve arzu ekseninde gerçekleşmektedir. Bakıldığında bu üç eksen cinayetlerin temel nedenine de denk düşmektedir. Kadın cinselliğinin denetimi ve sadakati ile ilişkilendirilen ve yıllardır varlığını sürdüren namus olgusu cinayetlerde kullanılan en popüler araçlardandır. Erkek denetiminin kaynağı olarak görülen namus olgusu, kadının cinsel saflığını muhafaza etmesinden ötürü taşıyıcı görevi verirken erkeği ise kadının namusundan kaynaklı şerefin sahibi olarak göstermektedir. Namus cinayetlerinin ortaya çıkmasındaki en önemli etki de bu sadakat ve korunmanın ihlalidir. Namusun kadın ve erkek için farklılaşan anlam ve yükümlülükleri bireyler tarafindan öğrenilmekte ve bu öğreti nesilden nesile aktarılarak varlığını sürdürmeye devam etmektedir.

Çalışmanın temel problemi olan öğrenilen namus algısının cinayet üzerindeki etkisine bakıldığında namusun kadının cinsel saflığı ve sadakatiyle ilişkilendirildiği görülmüştür. Bu kapsamda çalışmada yer alan vakada namusun kullanılış şekli ve gerekçesi namusa atfedilen anlama denk düşmektedir. Vaka derinlemesine incelendiğinde namus cinayetlerinin şartlarını sağladığı görülmektedir. Namus cinayetlerinin şartlarına baktığımızda temelde kadının cinselliğinin ve davranışlarının kontrolünün yattığı görülmektedir. Sağlıklı veya sağlıksız tüm bireylerde aynı anlamla varlığını sürdüren namus olgusu kadın bedeni üzerinde yaptırımlara sebep olmaktadır. Zira bu vakada gerçekle bağını koparan bireyin namusu kullanış şekli toplumsal değer ve normların değişmez iktidarının sonucudur.Bu açıdan bakıldığında toplumdaki baskın değerlerin değişmesi (namusun kadının cinsel saflığına ve sadakatine denk gelmesi gibi) kadın cinayetlerinin önlenmesi yönünde önemli bir adım olabilir.

\section{Kaynakça}

Aktaş, A.M. (2006). Aile İçi Şiddet Kadının ve Çocuğun Korunması, Ankara: Elma Yayınevi

Birleşmiş Milletler Nüfus Fonu, Türkiye deki Namus Cinayetlerinin Dinamikleri. https://turkey.unfpa.org/sites/default/files/pubpdf/namuscinayet.PDF (Erişim Tarihi: 25.08.2020).

Connell, R. W. (2017). Toplumsal Cinsiyet ve İktidar, İstanbul: Ayrıntı Yayınları.

Çelik, G. (2017). Öldüren Erkek(lik)ler (Eşine Şiddet Uygulamış Cezaevindeki Erkekler), İstanbul: Deniz Matbaa.

Doğan, R. (2016). Namus, Töre ve Eril Şiddet (Yargıtay Kararları, Toplumsal Cinsiyet Kuramları). Ankara: Ütopya Yayınevi.

Ecevitoğlu, P. (2012). Namus, Töre ve İktidar, Ankara: Dipnot Yayınları.

Engels, F. (1986). Ailenin, Özel Mülkiyetin ve Devletin Kökeni, Ankara: Sol Yayınları.

Hamzaoğlu, M. ve Konuralp, E. (2019). “Geleneksel Toplumlarda Namus Olgusu ve Namus Cinayeti: Türkiye Örneği”, İstanbul Üniversitesi Kadın Araştırmaları Dergisi, sayı 1, 54.

Hamzaoğlu, M. ve Konuralp, E. (2019). “Türkiye’de Kadına Karşı Şiddetin Sembolik ve Doğrudan Biçimleri: Namus Olgusu ve Namus Cinayetleri”, Adli Tıp Bülteni, 24(3), 232.

Moses, R. (1996). "Şiddet Nerede Başlıyor” Üç Aylık Düşünme Dergisi, sayı 6-7, 23.

Russel, B. (2014). Evlilik ve Ahlak. İstanbul: Cem Yayınevi.

Sakallı Uğurlu, N. ve Akbaş, G. (2013). "Namus Kültüründe "Namus" ve "Namus Adına Kadına Şiddet": Sosyal Psikolojik Açıklamalar" Türk Psikoloji Yazıları Dergisi, sayı 16, 80.

Şiddetten Ölen Kadınlar İçin Dijital Anıt (2008-2019). http://anitsayac.com/, (Erişim Tarihi: 26.08.2020).

T.C. Adalet Bakanlığı Muş Adliye Sarayı

T.C. Başbakanlık Atatürk Kültür, Dil ve Tarih Yüksek Kurumu Türk Dil Kurumu, http://tdk.gov.tr/index.php?option=com_gts\&arama =gts\&guid=TDK.GTS.5b10fb02ba8603.72181248, (Erişim Tarihi: 28.07.2020).

6284 sayılı Ailenin Korunması ve Kadına Karşı Şiddetin Önlenmesine dair Kanun, (2012). https://www.mevzuat.gov.tr/MevzuatMetin/1.5.6284 .pdf (Erişim Tarihi: 15.08.2020). 